\title{
EXTROVERSION, INTROVERSION AND STUDENTS' ACADEMIC PERFORMANCE OF SENIOR SECONDARY SCHOOLS IN JEGA LOCAL GOVERNMENT AREA OF KEBBI STATE, NIGERIA
}

\author{
Muza, S.H. \\ Department of Education \\ Kebbi State University of Science and Technology, Aliero \\ P. O. Box 1144, Aliero, Kebbi State, Nigeria \\ Tel: +234 7034907238 E-mail: $\underline{\text { muzask38@gmail.com }}$ \\ Sagir Muhammad \\ Department of Science Education \\ Kebbi State University of Science and Technology, Aliero \\ P. O. Box 1144, Aliero, Kebbi State, Nigeria \\ Tel: +234 8069779705 E-mail: sagiraliero@gmail.com \\ Dr. H. S. Aliero \\ Department of Education \\ Kebbi State University of Science and Technology, Aliero \\ P. O. Box 1144, Aliero, Kebbi State, Nigeria \\ Tel: +234 8069664268 E-mail: harunaaliero@gmail.com
}

\begin{abstract}
The study examined the relationship among extroversion, introversion and academic performance of senior secondary school students in Jega local government area of Kebbi State. Correlational research design was used for this study. Three null hypotheses were formulated to guide the study. The population of the study was 1,252 SS II students, proportional sampling technique was employed in selecting two hundred and ninety one (291) SS II students from six selected senior secondary schools within Jega local government area of Kebbi State. The results showed that, there is no significant relationship between extroversion and academic performance $(r=.025, p=.201)$. However, introversion is correlated with academic performance $(r=-.121, p=.040)$. There is significant difference between academic performance of extrovert and introvert students $(t$-cal $=47.181)$. From these findings, discussion was presented and the study recommended that, extroverted students should be extensively counselled on how to reduce social activities and pay more attention to their academics in order to improve their performance.
\end{abstract}

Keywords: Extroversion, Introversion, Academic Performance and Schools 


\section{Introduction}

Extroversion is the act, state, or habit of being predominantly concerned with and obtaining gratification from what is outside oneself, It manifest in a person and makes him enjoy human interactions and to be enthusiastic, takes pleasure in activities that involve large social gatherings, such as parties, community activities, public demonstrations and political groups (Webster, 2018).

Helgoe (2008) defined introversion as a state of being predominantly interested in one's own mental self. It enables a person to expand through reflection and dwindle during interaction. It is the act of directing one's interest inward or to things within oneself; the state of being concerned primarily with one's own thoughts and feelings rather than with the external environment.

\section{Differences between Extroversion and Introversion}

Crow and Crow (1963) as cited in Durosaro (2014) puts the major distinction between introverts and extroverts more succinctly in tabular form which is shown in Table 1 below.

Table 1. Differences between Extroversion and Introversion

\begin{tabular}{ll}
\hline Extroversion & Introversion \\
\hline Fluent in speech & Better in writing \\
Free from worries & Inclined to worry \\
Not easily embarrassed & Easily embarrassed \\
Governed by objective data & More influenced by subjective feelings \\
Friendly & Better reserved \\
Likes to work with others & Likes to work alone \\
Neglectful of ailments & Careful of ailments \\
Flexible and adaptable & Lacking in flexibility \\
\hline
\end{tabular}

To better understand student behaviour, we need to examine whether the student is an extrovert or an introvert, since the introvert may not be understood and judged appropriately (Durosaro, 2014).

Isaacs (2009) noted that, the main difference between the extrovert and the introvert is how each receives his/her energy. An extrovert is energized by external sources, such as people, activities and objects. Whereas introvert sources of stimulation are internal ones such as ideas, impressions 
and emotions. Extroverts and introverts also vary in their response to external stimulation. An extrovert thrives in an active setting and wants variety in the material presented.

According to De Raad and Schouwenburg (1996) as cited in Essays (2013), the personality factor that is most often linked to academic performance is conscientiousness. It encompasses the drive to accomplish things, which contains the characteristics necessary to pursue it such as: hard-working, achievement-oriented, organized, persistent, and careful (Goldberg, 2006). People who achieve good academic results usually possess most of these traits. Taylor (1964) as cited in Essays (2013) found that students who achieve good results are persistent and have the capacity to be hardworking for longer periods. Persistence is associated with conscientiousness (Oche, 2018). Extroversion and introversion are typically viewed as personality traits. The extroversion and introversion traits are the central dimension of human personality theories (Oche, 2018).

Jung (1995) in Oche (2018) submitted that extroverted person feels energized in the midst of other people, and is more prone to boredom when he is alone. People who are high in extroversion tend to seek out social stimulation and opportunities to engage with others, also manifested in outgoing, talkative and energetic behavior.

Introversion on the other hands, manifested in more reserved and often takes pleasure in solitary activities such as reading, writing, using computers, hiking and fishing. Jung (1995) defined introversion as an attitude-type characterized by orientation in life through subjective psychic contents (focus on one's inner psychic activity) and extroversion as an attitude type characterized by concentration of interest on the external object (the outside world).

Academic performance is an outcome of education. According to Ganai and Ashraf (2013) in Oche (2018), academic performance is the knowledge obtained or skills developed in school subjects usually designed by test scores or marks assigned by the teacher. It indicates the learning outcome of the students.

Browsard (2002) defined academic performance as the overall academic performance of the students in the school assessed by the use of teachers' rating tests and examinations. While United Nations (2010) postulated that academic performance includes standardized test scores in subject areas such as reading, mathematics and language arts; grade point average (s); classroom test scores and other formal assessments.

Academic performance and success rates of students revolve around the question of extroversion and introversion types that such students have (Oche, 2018). Consequently, if these variables are modified positively, then the level of students' academic performance would improve.

However, a review of the literature indicates that very few researches have been done in Nigerian context. Therefore, it is highly important to conduct a similar study to examine the situation in Jega metropolis. 


\section{Statement of the Problem}

Many students who wrote their final year examinations (WAEC) in 2016 to 2018 failed in English language and Mathematics which are the core subjects and as a result of this, several of them rewrote more than two or three times before they could get the requirements for admission into the university.

The problem of poor academic performance of secondary school students in Jega local government area is a great concern to stakeholders in education due to the huge investment on education, particularly on private schools education. This situation is worrisome in Jega local government area of Kebbi state. Therefore, there is a need to examine if relationship exists among extroversion, introversion traits with students' academic performance.

Despite all the various efforts by parents, teachers, State and Federal Governments to improve students' academic performance, the results still remained poor. For example, the 2012 examination results were very poor, where 80 percent of the candidates who sat for SSCE failed Mathematic and English (Adejor, 2012).

The numbers of candidates in Kebbi state with their percentages who sat for WAEC /SSCE examinations and obtained five credits including English language and Mathematics from 2016 to 2018 are: In May/June 2016 WAEC SSCE examination results, only $21.1 \%$ out of 27,052 in public schools and only $37.3 \%$ out of 399 in private schools' candidates got the required credit grades. In 2017 only $43.67 \%$ out of 27,134 in public schools and only $4.5 \%$ out of 111 in private schools' candidates, and $40.39 \%$ out of 30,112 in public schools and only $22,03 \%$ out of 57 in private schools' candidates in 2018 got five credits and above including English language and Mathematics (WAEC Results Statistics, 2016- 2018. 2018, pp. 42-43).

This poor academic performance could be linked to attitudinal variables of introversion and extroversion which may constitute a vital input that may have direct relationship with academic performance of students (Oche, 2018). As such, the need for empirical study becomes pertinent to investigate the relationship among extroversion, introversion and students' academic performance in Jega local government area of Kebbi state.

\section{Research Hypotheses}

The following hypotheses were formulated to guide the study:

$\mathrm{H}_{01}$. There is no significant relationship between extroversion and academic performance of senior secondary school students in Jega local government area.

$\mathrm{H}_{02}$. There is no significant relationship between introversion and academic performance of senior secondary school students in Jega local government area. 
$\mathrm{H}_{03}$. There is no significant difference between academic performance of extrovert and introvert students of senior secondary schools in Jega local government area.

\section{Significance of the study}

The significance of this study lies in providing insight about the academic performance of both extroverted and introverted students in senior secondary schools to give the teacher a better understanding of personality dimension of the students they are teaching in the classroom.

\section{Materials and Methodology}

\section{Research Design}

The study employed correlational research design. Correlational design according to McMilla and Schumacher (2010) is a research design in which information on at least two variables are collected in order to investigate the relationship between the variables.

\section{Population and sampling technique}

The population of this study is the entire SS 2 students (male and female) from the (6) six selected secondary schools which are 1,252, the sample of this study are two hundred and ninety one (291) respondents. The sample was selected in conformity with Krejcie and Morgan (1970). Stratified proportionate random sampling technique was used in the selection of sample from the various schools. It's also to ensure a proper representation of the entire population. The sample size of 291 SS 2 students was drawn from both public and private schools in Jega local government area.

Table 2. Distribution of the Secondary Schools by School Type, Population, Sample size and Percentage

\begin{tabular}{lcccc}
\hline Schools Name & School Type Population & $\begin{array}{c}\text { Sample } \\
\text { size }\end{array}$ & $\begin{array}{c}\text { Percentage } \\
\text { \% }\end{array}$ \\
\hline 1. Govt Sci. College, Basaura & Public & 172 & 40 & 14 \\
2. Govt Day Sec. Sch. Jega (Boys) & “ & 413 & 96 & 33 \\
3. Govt Day Girls Sec Sch. Jega & “ & 394 & 92 & 31 \\
4. Yassima International Sch, Jega & Private & 120 & 28 & 10 \\
5. Jega International School & “ & 131 & 30 & 10 \\
6. Quality Assurance, Jega & “ & 22 & 5 & 2 \\
Total & & $\mathbf{1 , 2 5 2}$ & $\mathbf{2 9 1}$ & $\mathbf{1 0 0}$ \\
\hline
\end{tabular}

Source: Zonal Education Office, Jega (2020) 


\section{Instrumentation}

The instrument used to collect data for this study was adapted from Eysenck (1967) in Oche (2018); it is called The Eysenck Personality Inventory (EPI). The bio-data consists of three questions which gives the information about the respondents' school name, gender and age. The instrument consists of twenty four (24) questions, which are classified into two sections. Twelve (12) items each were used to measure the feeling and act of the extrovert students and other 12 were used to measure the likes and dislikes of the introvert students. These aimed at finding out how the respondents study, feel, act and behave. Section B of the instrument measure how the extrovert students feel and act while section $\mathrm{C}$ measure the likes and dislikes of the introverted students. The students who scored high in extroversion test was placed as extroverted students and those who scored high in introversion test were placed as introvert students. Each question has four Likert point of: "Strongly Agreed (SA), Agreed (A), Disagreed (D) and Strongly Disagreed (SD)" rating 4, 3, 2 and 1 respectively.

\section{Academic Performance Scores}

The objectives test in English and Mathematics was constructed to collect data on academic performance of the respondents, this aimed at finding the academic performance of extrovert and introvert students. This instrument consists of twenty (20) objectives questions in English and Mathematics (10 for each subject). These questions have four options (A to D) where respondents were instructed to choose one answer and the scores were computed.

\section{Validity and Reliability of the Instruments}

Instruments used in this study were based on previous research conducted in Sabon Gari Local Government Area of Kaduna state by Oche (2018), the study is adopting a previously used and tested questionnaire, whose face and content validity is already tested. To ensure its reliability, a reliability test Cronbach Alpha for the Eysehnck Personality Inventory (EPI) is 0.985 respectively.

\section{Procedure for Data Collection}

The administration of the instrument was undertaken with the help of (2) two research assistants. Two (2) working days were used to administer the questionnaire along with the objectives test in English language and Mathematics to SS 2 students, a total of two hundred and ninety one (291) questionnaires were distributed and $100 \%$ retrieved and analyzed.

\section{Procedure for Data Analysis}

The data collected was analyzed using descriptive and correlation statistics for the purpose of either accepting or rejecting them. The scores from the test were analyzed using means and standard deviation, while Pearson Product Moment Correlation and Independent Sample t-test 
were used to test the hypotheses. All the hypotheses were tested at 0.05 alpha levels of significance.

\section{Results}

Demographic Data

Table 3. Distribution of the Respondents by Age

\begin{tabular}{cll}
\hline \hline Age of respondent & Frequency & Percent(\%) \\
\hline $16-20$ & 237 & 81 \\
$21-25$ & 46 & 16 \\
$26-30$ & 6 & 2 \\
30-Above & 2 & 1 \\
\hline Total & $\mathbf{2 9 1}$ & $\mathbf{1 0 0}$ \\
\hline \hline
\end{tabular}

\section{Source: primary data}

The results in the table 3 above show that the age bracket of SS2 students range between 16 to 20 years with $237(81 \%)$, this was followed by those who were between 21-25 years with $46(16 \%)$, 26-30 years were $6(2 \%)$ and lastly 30 and above were only $2(1 \%)$.

Table 4 Distribution of the Respondents by Gender

\begin{tabular}{lll}
\hline \hline Gender & Frequency & Percent(\%) \\
\hline Male & 179 & 62 \\
Female & 112 & 38 \\
\hline Total & $\mathbf{2 9 1}$ & $\mathbf{1 0 0}$ \\
\hline \hline
\end{tabular}

\section{Source: primary data}

Table 4 above reveals that the highest number of respondents were male with 179 (62\%), followed by female who were $112(38 \%)$. The difference between male and female was quite negligible and hence implied that both male and female responded positively towards the topic and had positive interest in the topic that was being investigated.

\section{Testing of Hypotheses}

Hypothesis One: There is no significant relationship between extroversion and academic performance in senior secondary school students. 
Table 5. Pearson Product Moment Correlation on Relationship between Extroversion and Academic Performance of the Students

\begin{tabular}{|c|c|c|c|c|c|c|}
\hline Variables & $\mathbf{N}$ & Mean & SD & Df & $\mathbf{r}$ & $P$ \\
\hline Extroversion & & 31.30 & 3.979 & \multirow{3}{*}{138} & \multirow{3}{*}{.025} & \multirow{3}{*}{.201} \\
\hline \multirow{2}{*}{\multicolumn{2}{|c|}{ Academic Performance }} & & & & & \\
\hline & & 11.20 & 3.860 & & & \\
\hline
\end{tabular}

Correlation is significant at the 0.05 level

The result of correlation coefficient tested, $\mathrm{r}=.025$ and $\mathrm{p}=.201$, in this result, the $\mathrm{p}$ value is higher than alpha value of 0.05 level of significance which means, there is no significant relationship between extroversion and academic performance of the students. Therefore, the null hypothesis is retained.

Hypothesis Two: There is no significant relationship between introversion and academic performance in senior secondary school students.

Table 6. Pearson Product Moment Correlation on Relationship between Introversion and Academic Performance of the Students

\begin{tabular}{|c|c|c|c|c|c|c|}
\hline Variables & $\mathbf{N}$ & Mean & SD & Df & $\mathbf{P}$ & \\
\hline Introversion & & 33.01 & 3.987 & & & \\
\hline \multirow{2}{*}{\multicolumn{2}{|c|}{ Academic Performance }} & & & 149 & $-.121 *$ & 0.040 \\
\hline & & 18.81 & 6.700 & & & \\
\hline
\end{tabular}

The result of the correlation in Table 6 revealed, $r=-.121$ and $\mathrm{p}=.040$, the $\mathrm{p}$-value is lower than alpha value of 0.05 level of significance which means, there is significant relationship between introversion and academic performance of the students. Hence, the null hypothesis is rejected.

Hypothesis Three: There is no significant difference between academic performance of extrovert and introvert students among senior secondary schools.

Table 7. T-test Analysis on Differences between Academic Performance of Extrovert and Introvert Students

\begin{tabular}{lccccccc}
\hline Variables & N & Mean & SD & SE & Df & t-cal & P \\
\hline Extroverts Academic & 140 & 11.20 & 3.860 & .222 & & & \\
Performance & & & & & & & \\
& & & & & 289 & 47.181 & 0.000 \\
Introverts Academic & 151 & 18.81 & 6.700 & .423 & & & \\
Performance & 291 & & & & & & \\
\hline
\end{tabular}


Table 7 shows significant difference in the performance of extrovert and introvert students $(\mathrm{t}=$ $47.181, \mathrm{p}=.000$ ) in favour of introverts. Further examination of the result revealed academic performance mean scores of extrovert and introvert students to be 11.20 and 18.81 respectively. This means that, academic performance of introvert students is higher than that of extrovert students. Therefore, the hypothesis which says, there is no significant difference between academic performances of extrovert and introvert students is rejected.

\section{Discussion}

The findings of the study showed that, hypothesis one was retained while hypotheses two and three were rejected. On the first hypothesis, there is no significant relationship between extroversion and academic performance of the students, the finding agreed with Essay (2013) whose findings indicated that extroversion and academic performance are not related. The study also agreed with Marin, Adolph and Welse (2008) who explained that, unsuccessful students had a higher chance of being more extroverts due to their ineffective study habits.

On the second hypothesis that, there is significant relationship between introversion and academic performance, this finding is in conformity with Michael (2015) who reported positive relationship between introversion and academic performance of students. Heffinerd (2014) agreed with this finding.

The last hypothesis which stated that there is significant difference between academic performance of extrovert and introvert students, disagreed with Soleimanil (2013) findings which reported that, there is no significant difference between extroversion-introversion dimension and their academic performance even though there was a small mean difference between them. It also disagreed with the finding of Durosaro (2014) who noted that, there is no significant correlation between students' academic performance and introversion/extroversion dimension.

\section{Conclusion}

Based on the findings of the study, the following conclusions were made:

The result of the finding revealed that, extroversion and academic performance are not related, because extroversion made students to have more interest in social activities than academic activities. The finding shows that, introversion is correlated to academic performance. Indicating that, introvert students pay attention to their studies through hard-working and seriousness. There is also significant difference between academic performance of extrovert and introvert students. From the results of the findings, there is difference between the academic performance of extrovert and introvert students in English language and Mathematics. This shows that introverted students are better in academic performance than their extroverted counterpart. 


\section{Recommendations}

Based on the findings of this study, the following recommendations were offered:

1. Every school, both public and private should try as much as possible to establish a counselling unit where students will be enlightened to understand their personality traits, which will enable them become more encouraged about their academic activities.

2. Parents and teachers should not regard introvert students as academically inferior to their extroverted counterparts; they should see it as a difference in personality characteristics.

3. The extrovert students should be provided teaching and learning facilities that will improve their academic performance. 


\section{References}

Adejor, S. (2012). WAEC result statistics (Mass Failure). Retrieved from www.nairaland.com/1006782/2012-2013 on 7th Sept., 2019.

Browsard, Z. (2002).Causes of Poor Achievement in WAEC Mathematics Examination in River State Secondary Schools Nigeria. International Journal of Mathematics Education, 21(3), pp. 110-120.

Durosaro, I. (2014). Relationship between introversion-extroversion and academic achievement among secondary school students in Oyo State.

Essays, U K. (2013). Personality influence academic performance. Psychology essay. Retrieved from http://www.ukessays.com/essays/psychology/personality influenceacademic-performance-psychology-essay.php?cref $=1$ on $20^{\text {th }}$ Feb., 2020.

Essays, U. K. (2015). Effects of extroversion on academic performance. Retrieved from www.ukessays.com/essays/psychology/... on $16^{\text {th }}$ Jan. 2020.

Essays, U. K. (2015). Extroversion personality and achievement relationship. Retrieved from: https://www.ukessays.com/essays/psycho on 28th Dec. 2019.

Eysenck, H. J. (1967). The biological basis of personality. Springfield, IL: Thomas Publishing.

Eysenck's Personality Inventory (1967). Extroversion and introversion Retreived from http://www.liaf-onlus.org/test/eysencks-personality-inventory-epi-extroversionintro version/24marz oadmin on 17th Dec., 2019.

Goldberg, L. R. (2006). "The international personality item pool and the f uture of publicdomain personality measures". Journal of Research in Personality, 40 (1).

Heffnerd, C. L. (2014). Personality Factors: The prediction of achievement and creativity. Indiana polls: The Babbsmarril Company, Inc.

Helgoe, L. (2008). "Introvert power: Why your inner life is your hidden strength". Naperville, Illinois: Sourcebooks, Inc.

Isaacs, T. (2009). Teaching and learning of introverted students. Open University System, Polytechnic University of the Philippines. Retrieved from http://www.facultyfocus.com /articles/teaching-and-learning/introverted-students-inthe-classroom-how-to-bring-out-their best/ on $25^{\text {th }}$ Jan., 2020.

Jung, C. (1995). Memories, dreams, reflections. London: Fontana Press. pp. 414-415. ISBN 0-00-654027-9.

Krejcie, R.V. \& Morgan, D. W. (1970). Determining Sample size for research activities in educational and psychological measurements. 607-610. New York: McGraw-Hill

Marin, L.; Adolph, K. E. \& Welse, I. (2008). Perceptual and motor development domain child... Infant/toddler learning and development foundations, California.

McMilla, J. H. Schumcher (2010). Education Research; Fundamentals for the consumer $\left(6^{\text {th }}\right.$ Edition)

Michael, F. (2015). Readings in extroversion-introversion: Bearing on basic psychological processes. New York.

Soleimanil, H. (2013). Extroversion/introversion and test performance of Iranian EFL students on multiple-choice and true/false reading comprehension test. Payame Noor 
University, Iran. International journal of English and education | www.ijee.org ISSN: 2. Oche, F. O. (2018). Relationship among extroversion, introversion and academic performance of senior secondary school students in Sabon gari local government area, Kaduna state. Unpublished Masters Dissertation submitted to faculty of education, Ahmadu Bello University, Zaria. Nigeria

United Nations (2009). Declaration of the Right of the Child. United Nations Office of Public Information. Retreaved on $16^{\text {th }}$ Jan. 2020 on http:/www.un.org

WAEC (2016-2018). Results statistics Kebbi state, 2016 to $2018 . \quad$ Retrieved from http://www.education.gov.ng on $9^{\text {th }}$ Feb., 2020.

Webster, M. (2018). Medical dictionary. Retrieved from https://www.merriamwebster.com/ dictionary/extraversion on 3rd Feb., 2020. 